\title{
Can the research university survive?
}

\begin{abstract}
Budgetary and other pressures are changing the character of US universities more quickly than is comfortable, but the process has only just begun. And it is not yet clear where it will end, to judge from a conference last week.
\end{abstract}

Los Angeles. Is the research university in the United States dead, or dying, or under threat of extinction? And, on the assumption that there is something to salvage from what will otherwise be rubble, what can be done to revitalize the university? That was the theme of a conference organized by the University of California, Los Angeles (UCLA), last week by Dr Kumar Patel, vice-chancellor for research at UCLA and by Dr Roland Schmitt, recently retired as president of the Rensselaer Polytechnic Institute, New York, under the challenging title "Reinventing the research university".

Improvement was more in evidence than re-invention. One speaker, Dr M. R. C. Greenwood, associate director for science at the Office of Science and Technology Policy at the White House, had earlier reminded her audience (university presidents, lesser academic mortals, civil servants and industrialists) of Clark Kerr's dictum, when chancellor of the University of California, that a university is a collection of disparate academic entrepreneurs united only by a "common grievance over parking".

Similarly, the research universities (of which there may now be 200 in the United States) have disparate goals, but are certainly united by their sense of grievance over "indirect costs" and over the federal government's apparent determination that these, the overhead payments accompanying research grants, should be restricted (by formula) and reduced. Luckily, the agenda last week ensured that the issue was only a passing reference in what most speakers said.

But money more generally is the root of the problem. Although the requests in this year's federal budget on behalf of the research-grant agencies include increases greater than the inflation rate, total discretionary expenditure is essentially fixed, so that later this year, and then for many years to come, the US Congress will be able to increase research support only by cutting other spending. (Greenwood said so explicitly; her listeners mostly took the point.) Dr Erich Bloch, president of the US National Science Foundation (NSF) in 1984-90, put it bluntly: the university research system has grown to a size and cost that cannot be sustained under the budget constraints ahead.

There are also other pressures on the system. Governments look to research universities for assurance on matters as different as industrial competitiveness and national security, but demand of the university system as a whole accountability, higher education of better quality and access for NATURE · VOL 369 • 30 JUNE 1994 greater proportions of young people. (More than half of high-school graduates in the United States already continue in some form of higher education.) The universities have taken fright at expressions of discontent with the quality of university education from students and their parents (who pay the bills) and employers (or non-employers).

How can the research universities survive these conflicting pressures? It seems agreed that the present is a period of rapid and irreversible change. The golden age of uninhibited growth has ended. But there is no consensus on what happens next. What follows is a thumbnail sketch of several strands of the argument last week.

Improvement, or being better at present tasks, is one tack. The general opinion is that the quality of teaching, especially of undergraduates, needs urgently to be improved. But no research university appears yet to have found a way of rewarding good teachers with promotion, even security. There is also palpable shame at the neglect of curriculum development, but touching faith that new-technology teaching, by means of networks and the like, may be radically more efficient. Self-assessment of effectiveness at reaching declared aims won general approval as a goal, but Schmitt (with practical experience at Rensselaer) declared flatly that most institutions do not even understand how their resources are spent on their different functions.

On the research side, there are several avenues for improvement, but none is decisive. Better management of projects, the more efficient use of what funds there are, more long-term block grants by NSF and the National Institutes of Health (to concentrate particular kinds of research where it is done best), more collaboration between institutions and the pooling of research facilities crop up on different people's menus. In this respect, last week's meeting closely echoed the discussions in Britain over the past decade about arrangements (now in place, but untried) for allocating research funds to the publicly supported universities. The difference was that, last week, the arguments were made by academics, not civil servants or their representatives. Plainly the research universities have seen the writing on the wall.

What do they make of it? For those of nervous disposition, the most alarming presentation would have been that of Dr Alexander MacLachlan, until recently senior vicepresident for research at DuPont, who openly explained that his company has abandoned its policy (of the 1970s) of throwing $\mathrm{PhDs}$ at fields of enquiry judged potentially rich in innovation, and instead is concentrating on its core businesses. The spur is the ferocity of international competition.

The corporation insists that its chief expectation of the research universities is a supply of skilled scientists; its recruitment of $\mathrm{PhDs}$ should pick up as the recession finally ends, but will not return to the dizzy earlier heights. Another is that DuPont, short of cash from having cut its margins to compete with overseas producers, is now seeking to pool its sense of penury with the penurious universities. MacLachlan said there have already been research contracts with university groups substituting for research that DuPont would previously have done in-house. In Japan, it used to be the case that some university departments would effectively be extensions of a company's research effort; is the United States about to move in that direction while the Japanese government is still formally committed to doubling spending on basic research?

It was plain last week that there are still huge difficulties to be ironed out - the freedom to publish, intellectual property rights and the like. But making university departments or research groups partly responsible for a corporation's research programme is radical enough to count as re-invention.

Dr Don Langenberg, the physicist deputy director of NSF in 1980-82 who is now chancellor of the University of Maryland system, went further with, for example, the concept of "Virtual-U" — a network linking academics with common interests. More radical, for the future of the research university, is the notion that parts of a university might be "unbundled" into a "collection of public enterprises" serving identifiable customers. He offered Maryland's new campus for continuing education as a sign of things to come.

Langenberg is an idealist in looking for an end to bickering between faculty and administration, a realist in acknowledging the importance of customers for university services and a manager tough enough to mould change rather than acquiesce in what happens. That is the sense in which "reinvention" is the right word. Last week's meeting may not have defined what the university of the future will be like, but it powerfully suggested that at least some universities have read the writing on the wall and have determined to make the best of it, however much change will be entailed.

John Maddox 